\title{
Information in referendum campaigns: how can it be improved?
}

\author{
Alan Renwick, Michela Palese, and Jess Sargeant \\ Constitution Unit, Department of Political Science, University College London
}

\begin{abstract}
Submission for Representation special issue 'Beyond "Direct Democracy": Referendums in Democratic Systems', edited by Alice el-Wakil and Spencer McKay
\end{abstract}

\begin{abstract}
Note
This is the final typescript of our article as submitted to the journal. It is not identical to the published version, and the latter should therefore be consulted before any citation.
\end{abstract}

\begin{abstract}
High-quality information is widely regarded as essential for democratic referendum campaigns, but what this means and how it can be advanced has not been systematically studied. By reviewing existing literature and drawing on a survey of practice around the democratic world, this article addresses this gap by making three contributions. First, it identifies four key dimensions to high-quality information: accuracy; balance; accessibility; and relevance. Second, it identifies four strategies through which information quality may be advanced: controlling campaign finance; confronting misinformation; creating and disseminating quality information; and promoting quality discussion. Third, it examines existing knowledge on the most promising of these strategies, offering preliminary conclusions and pointers for further research. The article suggests that the optimal strategy has not yet been found, and that further research could help to develop it.
\end{abstract}

\section{Keywords}

deliberation; democracy; information; referendum 


\section{Information in referendum campaigns: how can it be improved?}

The idea is widespread that the availability of high-quality information to voters is a key feature of the democratic strength of any referendum. But examination of what that means and how it may best be achieved remains piecemeal. This article seeks to address that gap by making three contributions. First, it proposes an account of what high-quality information means in the context of a referendum campaign, identifying four key dimensions: accuracy; balance; accessibility; and relevance. Second, it surveys different strategies for advancing high-quality information. Here again there are four elements; controlling campaign finance; confronting misinformation; creating and disseminating quality information; and promoting quality discussion. Third, it reviews what we currently know about the efficacy of these strategies, offers preliminary conclusions on them, and highlights areas where further research is needed.

We take referendums to encompass all official direct popular votes on questions of policy, irrespective of how these votes are initiated or what precise role they play in the policymaking process (cf. Butler and Ranney 1994: 1). While there are clear differences in how different types of referendum relate to the wider democratic system (see, e.g., el-Wakil and Cheneval 2018), the nature of the task that they ask voters to perform is essentially the same. The requisites for quality information are consequently commensurable too. Some differences may be pertinent, but they will not be our focus here.

\section{Referendums and democracy}

If democracy is rule by the people, there is an obvious sense in which greater use of referendums might be expected to entail stronger democracy: referendums allow direct popular control over specific policy decisions, rather than merely over the identities of the representatives who will make those decisions (e.g., Budge 1996). In addition, referendums sometimes engage public interest and participation in political decision-making to a degree that elections do not. The Scottish independence referendum of 2014 generated the highest ever turnout in a large-scale public vote in the UK, while the 2016 referendum on EU membership saw the highest UK-wide turnout since 1992. Countries such as Canada, France, Norway, and Poland have also recorded their highest turnout in recent decades in a 
referendum rather than in an election (Renwick 2017: 439-41). Furthermore, there is evidence that the existence of some kinds of referendum mechanism - particularly, citizeninitiated referendums - brings policy outcomes closer to public preferences (Leemann and Wasserfallen 2016; Lewis and Jacobsmeier 2017). El-Wakil (2017) argues specifically for the democratic value of so-called 'facultative' referendums, through which citizens can veto laws passed by the legislature.

On the other hand, referendums are not an unalloyed democratic good. There are multiple reasons for that (e.g., Rosenbluth and Shapiro 2018: 27-9; Weale 2018: 46-66). But we focus here on just one: a referendum is fully democratic only to the extent that voters can decide which option to vote for in a context of rich information and discussion. While populists may believe that 'the people' in their raw state know best what should be done, adherents of liberal, participatory, and deliberative conceptions of democracy all see processes of opinion development as critical (e.g., Barber 1984: 262; Setälä 2006: 701-3; Landemore 2018: 322). Campaigners need to be able to express their arguments and voters to hear them without structural bias. Voters cannot make a free choice if they are subject to overwhelming manipulations and distortions during the campaign (Bellamy 2018: 314; Chambers 2018: 309). In Barber's words, 'Referendum and initiative processes divorced from innovative programs for public talk and deliberation fall easy victims to plebiscitary abuses and to the manipulation by money and elites of popular prejudice' (Barber 1984: 263).

While deliberative approaches that emphasise informed decision-making are now standard in democratic theory (e.g., Dryzek 2017: 610), some empirical political scientists have argued that, in point of fact, extensive information does not matter in referendum campaigns. They contend that uninformed voters make the same choices as informed voters so long as they have basic information cues, shortcuts, or heuristics to follow. Most prominently, Lupia (1994), studying five ballot propositions relating to insurance reform in California in 1988, found that voters who knew the position of the insurance industry on these proposals but who could not answer factual questions about them voted in the same way as voters with both kinds of knowledge, but very differently from those with neither kind of knowledge. He concluded that fostering such cues 'may be a more effective and cost-efficient way to ensure the responsiveness of electoral outcomes to the electorate's preferences' than providing information about the issues in themselves (Lupia 1994: 72). 
Yet other studies reject this view. Multiple studies find that cues and heuristics are not sufficient to close the gap between informed and uninformed voters (e.g., Lau and Redlawsk 2001; Achen and Bartels 2016: 36-41). Experiments using deliberative polling, which raise information awareness to relatively high levels, often see substantial shifts in opinion (Luskin et al. 2002). More fundamentally, many democratic theorists see the value of an active and engaged citizenry as running much deeper than any measure of the voting gap between informed and uninformed voters can capture (e.g., Pateman 1970; Pettit 1997; Maynor 2003).

Indeed, concerns about information and discourse quality in referendums have long been expressed (e.g., Barber 1984: 285-6; Chambers 2001; LeDuc 2011; Pilon 2009; Renwick and Lamb 2013; Vowles 2013) and have become especially acute since the UK's 2016 referendum on EU membership (e.g., Deacon et al. 2016; Cushion and Lewis 2017; Offe 2017). Particular scholarly interest focuses on the relationship between referendums and deliberative democracy (Chambers 2001, 2018; Parkinson 2009; Gastil and Richards 2013; Landemore 2018). None of this is to say that voters should pay no attention to cues: it is entirely reasonable to consider information on others' positions when formulating one's own view. But the democratic process is vulnerable if that is all the information that is available.

\section{What is 'high-quality information'?}

Though the importance of information in referendum campaigns is widely recognised, the nature of the information that is required has not been fully explored. For example, LeDuc identifies 'the amount and quality of information' as one of 'four specific areas in which the conduct of referendums tends to inhibit deliberation' (LeDuc 2015: 140), but does not explicitly define the nature of the information that is needed. Barber comments, 'Information is indispensable to the responsible exercise of citizenship and to the development of political judgment' (Barber 1984: 278), but again leaves the concept undefined. So too does Chambers, who says that 'deliberative democrats are interested in enhancing the circulation and exchange of information, and promoting mutual reason-giving' (Chambers 2018: 308).

In order to address this gap, we have reviewed the existing scholarly literature and surveyed the rules and practices employed in referendums around the democratic world (see Renwick and Palese 2019; Renwick and Sargeant forthcoming). On this basis, and as explained below, Table 1 identifies four key dimensions of high-quality information: accuracy; balance; accessibility; and relevance. These dimensions are largely independent of each other: it is 
possible to advance any one without changing the others. All four are necessary to satisfy the needs of democracy.

Table 1. Four dimensions of high-quality information

\section{Accuracy}

- factual claims are not false or misleading

- future claims are justifiable and not exaggerated

\section{Balance}

- appropriate balance is maintained between different viewpoints

Accessibility

- information is readily findable

- information is readily understood

- information is engaging

Relevance

- information addresses all the issues voters care about

- information addresses all the matters that are affected

- information comes from sources that voters trust

Our first two dimensions - accuracy and balance - are very well established in the deliberative democracy literature. Fishkin's criteria for deliberation, for example, begin with the availability of 'reasonably accurate' information and 'substantive balance' among alternative perspectives (Fishkin 2009: 33-4). Steiner et al.'s original Discourse Quality Index (DQI) includes truthfulness as one of its six dimensions (Steiner et al. 2004: 19-20). Landemore (2018: 324) says that referendum voters should be able to 'go to the ballot booth with the objective and impartial information they need'. It is noteworthy that these two dimensions also dominate existing regulatory frameworks for structuring information in political contexts. In the UK, for example, the Broadcasting Code developed by Ofcom, the broadcasting regulator, is based on the principles of 'due accuracy' and 'due impartiality' (Ofcom 2017: section 5). Similarly, the Venice Commission - the legal advisory wing of the Council of Europe - advises in its Code of Good Practice on Referendums that 'The authorities must provide objective information', including 'a balanced presentation not only of the viewpoint of the executive and legislative authorities or persons sharing their viewpoint but also of the opposing one' (Venice Commission 2007: section I.3.1d). 
Despite wide acceptance of these two concepts - accuracy and balance - neither is entirely unproblematic. At its most basic, accuracy requires that factual claims should be neither false nor misleading. In the context of a referendum campaign, however, many claims are not strictly factual: rather, they are statements about what is likely to happen in the future if one or other of the options on the ballot paper is chosen. Accuracy in such cases requires that predictions be justifiable - for example, by being based on modelling that is rooted in existing knowledge.

The balance dimension is still more problematic. In Table 1, we have defined this criterion in terms of 'appropriate balance between different viewpoints'. But what does 'appropriate balance' mean? In fact, at least three definitions are credible: different perspectives may be given equal presence and credence; or they may receive presence and credence in proportion to their popular support; or they may gain presence and credence in proportion to their support among experts. The Venice Commission's referendum guidelines allow for both the first and second of these (Venice Commission 2007: section I.2.2.c-d). Ireland requires both official referendum information and broadcast reporting to follow the first very strictly (O’Mahony 2009: 434-5). Denmark, by contrast, is among the countries applying the second, by funnelling public funding for campaign activities through political parties in proportion to their support at the preceding election (Hobolt 2010). In various contexts, UK broadcasters employ all three: they have taken something close to the first approach during recent referendum campaigns; but in election campaigns, they employ the second, while on issues such as climate change they follow the third. Their interpretation of balance in the 2016 Brexit referendum has become contentious, with critics arguing that broadcasters were too inclined to give equal weight to different views even when one of these had much support among experts (Johnson 2016; Stubley 2018).

The reason that selecting among these different notions of balance is difficult is clear. The basic principle is that, to make their own judgement among competing arguments, voters must be able to hear those arguments. But one of the factors likely to shape voters' judgements is the amount of attention that different arguments receive. Information that projects 'false balance' can thus mislead (Koehler 2016; Dunwoody and Kohl 2017). In realworld political settings, therefore, some compromise between the alternative conceptions of balance is likely to be needed. 
Balance based on one or more of these conceptions is necessary for high-quality information in the referendum context. But which conception is targeted does not affect how it is best pursued. In the following sections we do not therefore advance any particular conception of balance; rather, we look at how balance conceived in any of these ways can be advanced.

Accuracy and balance are the dimensions of high-quality information that emerge most clearly from existing literature and practice. But they are insufficient to constitute highquality information on their own. In particular, information that is balanced and accurate will achieve little if people struggle to access it or if it is not the information that people want or that will help voters make informed choices. This leads to our third and fourth dimensions, relating to accessibility and relevance.

Accessibility requires that people can readily find the information, that they can understand it, and that they find it engaging. LeDuc highlights one aspect of accessibility, relating to the danger of information overload in referendums on complex packages such as international treaties: 'The Treaty Establishing a Constitution for Europe ran to just under five hundred pages of complex legal text. Even a summary of the document widely circulated during the campaigns ran to over ninety pages' (LeDuc 2015: 144). More basic is the simple need for information to be available to citizens without needing to search for it: the Venice Commission, for example, states that information 'must be sent directly to citizens and be received sufficiently far in advance of the vote' (Venice Commission 2007: section I.2.2.d).

Relevance, finally, requires that information should address the issues that matter in the referendum. What 'the issues that matter' are may naturally be subject to discussion and disagreement. As we saw above, one perspective within empirical political science sees voters as needing only 'cues': information on how people whose judgement they trust or distrust intend to vote. On this view, cue-takers, at least in some circumstances, vote in just the same way as voters who are informed about the issue in itself, and further information therefore makes no difference (Lupia 1994, 2016: 40-55). Cues, as we have recognised, are clearly important to all of us in developing our views on issues. Reflecting this, one of the aspects of relevance that we emphasise in Table 1 is that information should come from sources that voters trust. Citizens will not see information as relevant to them if it comes from sources that they do not regard as credible. As we argued above, however, if voters have access to cues alone, free decision-making and the deeper values of participatory or 
deliberative democracy are endangered. Information on the substance of the issue therefore matters too.

For referendums on narrow, self-contained topics, what that substance is may be obvious. But where voters are asked to determine more complex issues, it may be harder to define. We allow in Table 1 for two aspects of substance: the issues that voters themselves care about; and the issues that might be affected by the outcome of the referendum. The first of these deserves to be highlighted, as it can be easy for policy experts to lose sight of the issues that shape voters' own decision-making. During the Brexit referendum in 2016, for example, many voters apparently felt that the data and forecasts produced by economists - focusing on the national economy - bore little relation to their own lived experience around the country (e.g., Chakrabortty 2017). If people's actual concerns are not addressed in the information that is available, they are unlikely to pay it much attention. At the same time, there may be issues of importance - issues that are likely to have a major impact in the future - that, for whatever reason, have not yet risen to prominence in the public consciousness. To take another Brexit example, the issue of the border between Northern Ireland and the Republic of Ireland was highlighted by some experts during the referendum campaign (e.g., Donnelly 2016), but received little wider public attention (Deacon et al. 2016: 34). It is an important requisite of high-quality information that it should overcome such deficits.

To check the robustness of this four-dimensional characterisation of high-quality information, Table 2 compares this characterisation with two others. These are taken from two of the most widely cited delineations of information quality in the information science literature. Miller (1996) identifies ten dimensions, while Kahn et al. (2002) distinguish sixteen. In each case, all but one of these dimensions fit within our proposed four dimensions. Accuracy is highlighted in both studies: indeed, Miller has two dimensions - accuracy and validity - that substantially overlap with each other in this area. Both studies distinguish multiple aspects of accessibility, reflecting a greater focus on aspects of format and presentation than we attempt. Their dimensions, like ours, highlight the need for information to be easily reached, understandable, not overwhelming, and engaging. The various aspects of relevance that the studies identify also correspond closely to our own. 
Table 2. Dimensions of high-quality information: comparison of delineations

\begin{tabular}{lll}
\hline Our dimensions & Miller (1996) & Kahn et al. (2002) \\
\hline accuracy & $\begin{array}{l}\text { accuracy } \\
\text { validity } \\
\text { coherence }\end{array}$ & free-of-error \\
\hline balance & & objectivity \\
\hline accessibility & accessibility & accessibility \\
& compatibility & ease of manipulation \\
& completeness* & appropriate amount \\
format & concise presentation \\
& & consistent presentation \\
& & interpretability \\
& & understandability \\
\hline relevance & relevance & relevancy \\
& completeness* & completeness \\
& timeliness & timeliness \\
& & value-added \\
& believability \\
& reputation \\
\hline
\end{tabular}

* We list Miller's 'completeness' dimension twice, as it straddles two elements: whether information covers all the relevant issues; and whether it is too overwhelming to be accessible.

There are two areas of difference between our characterisation and theirs. First, we place greater emphasis on the need for balance. This dimension is absent from Miller's account, while Kahn et al. approach it only in their concept of 'objectivity', by which they mean 'the extent to which information is unbiased, unprejudiced, and impartial' (Kahn et al. 2002: 187). This difference is understandable: balance is needed in some contexts but not in others; it is crucial in democratic politics, but the authors of these studies are primarily interested in information for business customers, where it is unlikely to be a priority. Second, both studies include a dimension of security. This is clearly important, but it is about the management of information systems rather than the character of information in itself, and so lies outside our inquiry.

We are therefore confident that our conception of high-quality information in the context of referendum campaigns provides a solid starting point for further investigation. We next seek to identify ways in which such information may be promoted. 


\section{Strategies for enhancing information quality in referendums}

There is no reason to think that information meeting these standards will automatically come available during referendum campaigns in the absence of conscious efforts to promote it. For example, campaigners may find that making misleading claims advances their cause, and imbalances in the funding available to the different sides may skew debate. It is therefore important to identify strategies that might enhance information quality in the context of referendum campaigns. Drawing again on our surveys of scholarly literature and existing democratic rules and practices, we identify four broad families of strategy, as summarised in Table 3.

Table 3. Strategies for improving information quality in referendums

\begin{tabular}{|c|c|c|c|}
\hline Strategy & Description & $\begin{array}{c}\text { Targeted } \\
\text { dimensions of } \\
\text { information quality }\end{array}$ & Examples \\
\hline $\begin{array}{l}\text { Controlling } \\
\text { campaign } \\
\text { finance }\end{array}$ & $\begin{array}{l}\text { measures to } \\
\text { constrain } \\
\text { donations and/or } \\
\text { spending }\end{array}$ & balance & $\begin{array}{l}\text { donation limits: Portugal, } \\
\text { Lithuania } \\
\text { spending limits: UK, New } \\
\text { Zealand }\end{array}$ \\
\hline $\begin{array}{l}\text { Confronting } \\
\text { misinformation }\end{array}$ & $\begin{array}{l}\text { measures to ban or } \\
\text { expose } \\
\text { misinformation }\end{array}$ & accuracy & $\begin{array}{l}\text { bans on false information: } \\
\text { France, South Australia } \\
\text { fact-checking: US, UK } \\
\text { transparency: US, Ireland }\end{array}$ \\
\hline $\begin{array}{l}\text { Creating and } \\
\text { disseminating } \\
\text { high-quality } \\
\text { information }\end{array}$ & $\begin{array}{l}\text { measures to create } \\
\text { and promulgate } \\
\text { high-quality } \\
\text { information }\end{array}$ & $\begin{array}{l}\text { accuracy, balance, } \\
\text { accessibility, } \\
\text { relevance }\end{array}$ & $\begin{array}{l}\text { information booklets: } \\
\text { California, Switzerland } \\
\text { information campaigns: } \\
\text { Ireland, New Zealand }\end{array}$ \\
\hline $\begin{array}{l}\text { Promoting } \\
\text { high-quality } \\
\text { discussion }\end{array}$ & $\begin{array}{l}\text { measures to foster } \\
\text { public deliberation } \\
\text { and promulgate } \\
\text { results }\end{array}$ & $\begin{array}{l}\text { accuracy, balance, } \\
\text { accessibility, } \\
\text { relevance }\end{array}$ & $\begin{array}{l}\text { citizens' assemblies: Canada, } \\
\text { Ireland } \\
\text { citizen initiative reviews: } \\
\text { Oregon }\end{array}$ \\
\hline
\end{tabular}




\section{Controlling campaign finance}

The aspect of referendum campaign regulation that has received the most long-standing scholarly attention relates to campaign finance. Political scientists have long asked whether imbalances in campaigners' spending resources affect the outcome (e.g., Owens and Wade 1986; Cronin 1989; Bowler and Donovan 1998; Gerber 1999; De Figuereido, Ji and Kousser 2011; Rogers and Middleton 2015). The conclusion, shared by most of these studies, that financial advantage does bring a greater chance of victory leads to support for campaign finance regulations (Barber 1984: 285; LeDuc 2015: 145; Chollet 2018: 345).

Reidy and Suiter (2015) have surveyed such regulations as they exist in contemporary democracies in detail. They identify five main dimensions: bans or limits on donations; bans or limits on expenditure; financial disclosure requirements; public funding provisions; and rules on enforcement and sanctions (Reidy and Suiter 2015: 162). They find considerable variation across democracies in the extent of campaign finance regulation, from countries, such as Switzerland and Luxembourg, with no or very few rules to countries, including the Czech Republic and the UK, with many rules (Reidy and Suiter 2015: 166).

For the purposes of our analysis here, campaign finance regulation focuses almost entirely on just one of the dimensions of high-quality information: namely, balance. It is designed to ensure that the information that voters receive in the course of a campaign is not unduly skewed in one direction, but it does nothing to address the content of that information in terms of accuracy, accessibility, or relevance.

\section{Confronting misinformation}

Our second family of strategies seeks to confront misinformation, with the aim either of preventing its dissemination or weakening its power. The strategies in this category are again directed at only one of the four dimensions of information quality: in this case, accuracy.

In the bluntest form of this approach, specified types of misinformation are banned during referendum campaigns, and provisions are introduced to enforce this. A law to this effect has recently been introduced in France (Loi n ${ }^{\circ}$ 2018-1202 du 22 décembre 2018 relative à la lutte contre la manipulation de l'information). The most developed such provision in any democracy exists in South Australia, where the Electoral Act empowers the Electoral

Commission to require the withdrawal of any campaign advertisement that 'contains a statement purporting to be a statement of fact that is inaccurate and misleading to a material 
extent' (Electoral Act 1985 (South Australia), as amended, section 113(2); see Renwick and Palese 2019: 22-30 for detailed discussion). More subtle are strategies for fact-checking, through which misinformation is identified and exposed as such. More indirect still are requirements for transparency as to what information is provided by whom to whom, allowing anyone who wishes to check what this information contains.

A substantial literature has recently developed in this area, particularly in relation to factchecking. Some studies emphasise the limits to fact-checking's utility, finding that it can generate 'backfire effects' (Nyhan and Reifler 2010) and that 'belief echoes' can survive even if voters accept the fact-checkers' conclusions (Thorson 2016) - though others are more optimistic (Wood and Porter 2019). Our own research into the impact of misinformation bans in Australia and New Zealand, meanwhile, suggests that, while such mechanisms can operate efficiently and in a way that is widely trusted and regarded as legitimate, they have only a limited impact on the quality of information or the wider tenor of debate (Renwick and Palese 2019: 22-30).

Indeed, there is no way a misinformation ban could effect change beyond the margins of discourse without impinging on free speech. If campaigners want to leave a misleading impression, they can generally do so without saying anything that is strictly false. And for a public authority to intervene against political statements that are not strictly false would be highly problematic. To give a prominent example from the UK's Brexit referendum, the statement 'We send the EU $£ 350$ million a week’ (which appeared on the Leave campaign’s infamous bus) was strictly false. But the statement 'Britain's official bill for EU membership is $£ 19$ billion per year or $£ 350$ million every week’ (which appeared on a Vote Leave leaflet) was not, though it was clearly intended to leave the same impression. An intervention that could address only the first of these could achieve little.

\section{Creating and disseminating quality information}

The third family of strategies involves providing high-quality information. In contrast to the previous, reactive approach, the strategies in this family are proactive: the goal is to generate high-quality information and disseminate it as widely as possible among voters. Whereas the first two families of strategies each addressed only one of the four dimensions of information quality, this approach can target all four.

Information of various kinds can be provided. At its most basic, it is purely procedural, covering when the referendum will be held and how voters can cast their ballot. Such 
information may be accurate, balanced, and accessible, but clearly cannot address all the matters that are relevant to voters in deciding how to vote. At the other extreme, detailed information can explain the options, analyse what can be known about the effects of each, and help voters make their choice. The further information goes in this direction, the better it can satisfy the relevance criterion, but the harder it is to maintain accuracy, balance, and (at least in referendums on complex matters) accessibility.

Information that is designed to help voters navigate their way around the arguments may take at least four different forms. First, it may seek to set out the effects of a proposal objectively, without directly relating these to arguments. The intention is that voters will then be better resourced to evaluate the arguments that they hear from campaigners in the course of the campaign. This approach has been taken in referendums in Ireland since 2001. A Referendum Commission comprising neutral public servants is established for each referendum. It produces a booklet, website, and advertising campaign in which it explains the choice available to voters and the legal effects of each option (O'Mahony 2009). This can score well in terms of accuracy, balance, and accessibility, but, as we explain below, it may not help voters evaluate all of the arguments fully, thus falling down in terms of relevance (Renwick and Palese 2009: 128-44).

Second, campaign groups may be given equal opportunities to spell out their case in their own terms. In the UK's 2016 Brexit referendum, for example, the Electoral Commission sent a leaflet to all households that, aside from basic information on what the question was and how voters could participate, included a page provided by each campaign group. In California, the Voter Information Guide also contains statements from groups on both sides of the debate (LeDuc 2015: 144). Such provision is likely (in the round) to score highly in terms of balance and accessibility, but may be deficient on accuracy and relevance. The Californian booklet includes rebuttal statements in which each side responds to the arguments of the other, but limited space and the absence of a neutral voice makes it unlikely that this will provide space for revealing nuanced realities.

Third, the arguments on each side may be set out by a neutral body. This approach was taken in Ireland when the practice of establishing Referendum Commissions was first adopted, between 1995 and 2001 (O’Mahony 1998; Renwick and Palese 2009: 128-44). At least in principle, this approach can score highly on all four dimensions of information quality. 
Finally, rather than providing pro and con statements, information may set out criteria that might be used to evaluate the options and then indicate how each option performs in terms of these criteria. This approach has been used in referendums in New Zealand since 1992 (Renwick and Palese 2019: 144-60). In several referendums on the electoral system, for example, criteria such as 'effective government', 'fairness', and 'voter participation' have been identified, and the various systems on the ballot paper assessed in terms of each. No attempt is made to advise voters as to how much weight they should attach to each criterion, so the information does not constitute guidance on how to vote. The goal is, rather, that voters should have the resources to decide their own priorities and come to their own judgement. This approach aims to score highly on all four dimensions of information quality.

It is also possible to combine these approaches. In Switzerland, for example, the information booklet that is sent to all voters with their ballot papers includes both a factual outline of the issue in question prepared by the federal government and statements of arguments prepared by the proponents of each side.

\section{Promoting quality discussion}

Our final family of strategies goes beyond top-down information provision by seeking to engage voters in deliberative discussions about the referendum issues. The most ambitious form of this approach endeavours to draw all voters directly into such discussions: Ackerman and Fishkin (2004), for example, propose a 'deliberation day' preceding federal elections in the United States, and Ackerman and Le Grand (2018) have suggested extending the approach to referendums. The practical obstacles to implementing such a scheme are, however, high. Less ambitious, but more realistic, are strategies through which small numbers of citizens participate in so-called deliberative mini-publics, such as citizens' assemblies or citizens' juries, whose conclusions are then disseminated across the electorate.

Deliberative mini-publics have been used in the context of referendums in two ways (cf. Landemore 2018). First, they have been used to set the agenda for referendums, deciding or making recommendations on what (if any) proposals should be put to voters. The key examples of this are in the Canadian provinces of British Columbia and Ontario on the subject of electoral reform (Fournier et al. 2011; Warren and Pearse 2008) and in Ireland on a variety of topics, most prominently including same-sex marriage and abortion (Elkink et al. 2017; Suiter 2018a, 2018b). In each case, an assembly of randomly selected citizens has met over multiple weekends to hear from campaigners, experts, and others with relevant 
experience, deliberate among themselves, and draw conclusions. Those conclusions and the thinking underlying them have then been written up in a report and (to varying degrees) disseminated among voters.

Second, mini-publics have been used to frame the debate in referendum campaigns, where the proposal on the ballot paper has already been fixed. This has been pioneered in the state of Oregon through the process of 'citizens' initiative reviews', where, at most recent election seasons, a panel of randomly selected citizens has convened several months ahead of polling day to consider one ballot proposition. As in the case of citizens' assemblies, they hear from campaigners and experts, deliberate, and reach conclusions. They then produce statements on each side of the debate, setting out the arguments that they think their fellow citizens ought to attend to. These statements are included in the information booklet sent to all voters (Gastil and Richards 2013; Gastil et al. 2015).

Each of these ways of using mini-publics seeks to advance information of high quality on all four dimensions. In particular, because information is generated by ordinary members of the public, the intention is that it should score highly in terms of relevance: it should address ordinary voters' concerns; and voters may be more likely to trust information developed by people like them than information coming from a distant elite. On the other hand, there may be concerns that information generated by regular citizens rather than experts may suffer in terms of accuracy and balance. We consider evidence on these various expectations below.

\section{Existing knowledge and further research}

Of the four families of strategy identified in the preceding section, two aim to advance just one of the dimensions of information quality, while the remaining two strive to advance information quality in the round. We now concentrate on the latter, examining very briefly what is already known about them, what preliminary conclusions can be drawn, and what further research is needed. We draw partly on existing literature and partly on our own research, conducted for a report looking at ways of improving information and discourse in elections and referendums in the UK (Renwick and Palese 2019). In each case, we look at how well the information generated by these strategies in itself meets the standards of accuracy, balance, accessibility, and relevance and at how far it advances these same features in the wider information environment during the campaign. 


\section{Information provision}

We have found no comparative literature on conventional referendum information campaigns, though there are valuable single case studies (e.g., McRobie 1993; O’Mahony 1998, 2009). We therefore conducted our own case studies of practice in Ireland and New Zealand (see Renwick and Palese 2019: 125-63 for details). We focused on these countries because they exemplify three of the four versions of this strategy outlined above: Ireland's Referendum Commissions seek to provide objective information of the effects of the options; between 1995 and 2001, those Commissions also set out pro and con arguments on each side; New Zealand takes the most ambitious approach of any country, explaining the options, setting out criteria for their evaluation, and presenting the evidence on how each option performs on each criterion.

Unsurprisingly, all three cases score well in terms of the accuracy of the information materials in themselves, which are produced through meticulous processes engaging multiple experts. We interviewed people who had taken part in this process at multiple referendums in each country, and all were confident that accuracy was attainable. We also surveyed newspaper coverage and found no dissent from this view. The same pattern is largely true for balance. Interviewees were confident they had maintained it. In New Zealand, our newspaper analysis, which covered a 2011 referendum on electoral reform, identified no criticism on this score (Renwick and Vowles 2019). We did find some accusations of partiality on the part of the Referendum Commissions in Ireland, but these were rare. Information providers in both countries have become savvier over time in maximising the accessibility of their materials, developing increasingly sophisticated and attractive websites alongside traditional leaflets, and most recently building their presence on social media.

Where we found the greatest variation in the information materials between the cases was in their relevance to the key matters of debate within the referendum. Ireland's Referendum Commissions have focused since 2001 on setting out the legal effects of each option on the ballot paper. That means that they have sometimes missed crucial issues beyond the law. In the 2008 referendum on the Lisbon Treaty, for example, the Commission's booklet set out the proposed changes to EU decision-making processes and activities in detail. But anyone seeking help in interpreting the different campaigners' claims as to the practical implications of all these changes would have searched in vain. In New Zealand, by contrast, the criteria used to evaluate the options are rooted in the arguments present within the public debate. 
The impact of these information campaigns on wider discourse is hard to judge on existing evidence. Interviewees in both countries thought the campaigns were valuable, though some in Ireland accepted this value was limited. Public opinion surveys have not, however, asked comparable questions across the two countries. Levels of media attention measured by the proportion of newspaper articles relating to each referendum mentioning the information materials have been broadly comparable, though journalists have been more likely to draw on the content of those materials to inform their reporting in New Zealand. In a related study, we have found levels of accuracy in the wider referendum discourse to be notably high in New Zealand (Renwick and Vowles 2019), but the degree to which this can be attributed to the information campaign is hard to judge.

Overall, New Zealand's experience shows that it is possible to run a highly ambitious referendum information campaign providing considerable information that should help voters in interpreting the debate and making their choice. Information in Ireland, particularly since 2001, has appeared more limited in its usefulness. Further research is needed, however, to establish robustly whether these differences affect the impact of the information campaigns on information quality in the wider discourse.

\section{Deliberative mini-publics}

As the references in the section above on promoting public discussion attest, recent scholarly literature has shown much more interest in the use of deliberative mini-publics in the context of referendums than it has in more traditional public information campaigns. The materials generated by such mini-publics score highly in terms of accuracy, balance, and accessibility (Fournier et al. 2011: 83-93; Gastil et al. 2015: 25-9, 73). We have not seen evidence on whether they succeed in addressing the issues that matter to ordinary voters, though, as noted above, the composition of deliberative mini-publics makes it logical to expect this. There is evidence that voters trust such bodies: studies in both Canada (Fournier et al. 2011: 131-2) and Ireland (Elkink et al. 2017: 370; Suiter 2018a) indicate that voters are more likely to trust citizens' assemblies than political campaigners and that those who know about a citizens' assembly are more likely to support its conclusions.

Evidence on the wider impact of mini-publics is mixed. Studies of both Canadian cases have doubted any substantial effect and criticised politicians for failing to enable the voice of the citizens' assemblies to be heard in the subsequent referendum campaigns (Ratner 2008: 146; LeDuc et al. 2008: 33). In Ireland, by contrast, commentators have argued that the effect of 
the assemblies - particularly on discourse during the 2018 abortion referendum - was transformative (e.g., Carr 2018), and findings from political science support that (Suiter 2018b). In Oregon, Gastil and colleagues find that many voters say the citizens' initiative review statements are useful (Gastil et al. 2015: 35-8, 2017: 17-20). But this positive impression needs to be tempered by experience in 2018: no review process was established that year, but our review of newspaper coverage and legislative debates found no reaction to that: it appears that citizens' initiative reviews were not valued sufficiently to be missed when they did not occur. More attention needs to be given to how deliberative mini-publics such as these connect with the wider public during referendum campaigns (cf. McKay 2018: 332) - a conclusion that fits with a major theme in contemporary deliberative democracy research (Parkinson and Mansbridge 2012; Curato and Böker 2016).

\section{Conclusions}

There is wide agreement that high-quality information should be available to voters during referendum campaigns and that contemporary referendums are often far from meeting that mark. But little attention has been given to what high-quality information in this context is or how it can best be promoted. We have sought in this article to begin addressing this gap. We have identified four dimensions of high-quality information: accuracy, balance, accessibility, and relevance. We have also identified four strategies for advancing these - controlling campaign finance; confronting misinformation; creating and disseminating quality information; and promoting quality discussion - and have surveyed real-world variants of each. Finally, we have briefly investigated what we already know about the most ambitious and promising of these strategies.

Current knowledge is too limited to permit firm conclusions. But several preliminary observations emerge. First, none of the four strategies is likely to optimise information on its own. Rather, an approach that combines elements of all of them looks preferable. Citizens should be able to hear all the arguments and have resources enabling them to identify misinformation. They should have access to quality information from a range of sources, including campaigners, experts, and members of the public who have deliberated in depth. Second, substantial resources need to be put into public information campaigning if it is to have a significant impact on the wider discourse. In New Zealand, budgets for such official information have been set higher than the spending limits for campaigners, and something 
approaching this ethos might be applied elsewhere too. Creative development and promotion of materials tailored to suit a wider variety of audiences is needed. Third, there remains scope to be more creative also in how citizen deliberation is integrated into information generation. Citizen panels might, for example, guide the criteria that are used in official information materials or be used to influence the claims that are assessed by fact-checkers.

Thus, while we have reviewed existing practice here, we suspect that it would be possible to do much more than has been achieved in any democratic polity so far. If we care about the health and depth of democracy, we should conduct further research into the promising options that have been identified here and how they could be developed further.

\section{Acknowledgements}

This work was supported by the McDougall Trust, to whom we are grateful. The authors also thank the editors of this special issue and two anonymous reviewers for their comments on earlier drafts. Responsibility for all errors and other weaknesses remains, of course, our own.

There are no conflicts of interest to report in connection with this article.

\section{Biographical notes}

Alan Renwick is Associate Professor in British Politics and Deputy Director of the Constitution Unit at University College London. He has published widely on electoral reform, referendums, and deliberative democracy. He was Director of the Citizens' Assembly on Brexit in 2017 and Research Director for the UK's Independent Commission on Referendums in 2017-18.

Michela Palese was Research Assistant and McDougall Fellow at the Constitution Unit, University College London.

Jess Sargeant was Research Assistant at the Constitution Unit, University College London. 


\section{References}

Achen, Christopher H., and Larry M. Bartels (2016). Democracy for Realists: Why Elections Do Not Produce Responsive Government. Princeton: Princeton University Press.

Ackerman, Bruce, and James S. Fishrin. 2004. Deliberation Day. New Haven: Yale University Press.

ACKERMAN, BRUCE, and JULIAN LE GRAND (2018). How to have a serious referendum on Brexit and avoid a rerun of the original. LSE British Politics and Policy blog, 31 May.

Barber, Benjamin J. 1984. Strong Democracy: Participatory Politics for a New Age. Berkeley: University of California Press.

BELlamy, RichaRD. 2018. Majority rule, compromise and the democratic legitimacy of referendums. Swiss Political Science Review 24 (3): 312-19.

Bowler, Shaun, and Todd Donovan. 1998. Demanding Choices: Opinion, Voting, and Direct Democracy. Ann Arbor: University of Michigan Press.

Budge, IAn. 1996. The New Challenge of Direct Democracy. Cambridge: Polity Press.

Butler, David, and Austin RanNey. 1994. Practice. In Referendums around the World: The Growing Use of Direct Democracy, edited by David Butler and Austin Ranney. Basingstoke: Macmillan, pp. 1-10.

CARr, MARY. 2018. Citizens' Assembly has proven a success - but it must not be a mudguard for elected decision makers. Irish Daily Mail, 28 May.

ChaKrabortty, Aditya. 2017. One blunt heckler has revealed just how much the UK economy is failing us. The Guardian, 10 January.

Chambers, Simone. 2001. Constitutional referendums and deliberative democracy. In Referendum Democracy: Citizens, Elites and Deliberation in Referendum Campaigns, edited by Matthew Mendelsohn and Andrew Parkin. Basingstoke: Palgrave, pp. 231-55.

CHAMBers, SimONE. 2018. Making referendums safe for democracy: a call for more and better deliberation". Swiss Political Science Review 24 (3): 305-11.

Chollet, Antoine. 2018. Referendums are true democratic devices. Swiss Political Science Review 24 (3): 342-7. 
Cronin, Thomas E. 1989. Direct Democracy: The Politics of Initiative, Referendum, and Recall. Cambridge, MA: Harvard University Press.

Curato, Nicole, and MARIT BÖKeR. 2016. Linking mini-publics to the deliberative system: a research agenda. Policy Sciences 49 (2): 173-90.

CUSHION, StePhen, and JUSTIN LEWIS. 2017. Impartiality, statistical tit-for-tats and the construction of balance: UK television news reporting of the 2016 EU referendum campaign. European Journal of Communication 32 (3): 208-23.

Deacon, David, John Downey, Emily Harmer, James Stanyer, and Dominic Wring. 2016. The narrow agenda: how the news media covered the referendum. In EU Referendum Analysis 2016: Media, Voters and the Campaign edited by Daniel Jackson, Einar Thorsen, and Dominic Wring. London: Political Studies Association, pp. 34-5.

De Figueiredo, John M., Chang Ho Ji, and Thad Kousser. 2011. Financing direct democracy: revisiting the research on campaign spending and citizen initiatives. Journal of Law, Economics, and Organization 27 (3): 485-514.

DonnELly, BRENDAN 2016. Troubles redux: Brexit would put the Good Friday Agreement in jeopardy. LSE Brexit blog, 28 April.

DryzeK, JoHn S. (2017). The Forum, the System, and the Polity: Three Varieties of Democratic Theory. Political Theory 45(5): 610-36.

Dunwoody, SHARON, and PATRICE A. KOHL. 2017. Using weight-of-experts messaging to communicate accurately about contested science. Science Communication 39 (3): 338-57.

Elkink, Johan A., David M. FARrell, Theresa ReIDy, and Jane Suiter 2017. Understanding the 2015 marriage referendum in Ireland: context, campaign, and conservative Ireland. Irish Political Studies 32 (3): 361-81.

EL-WAKIL, ALICE 2017. The deliberative potential of facultative referendums: procedure and substance in direct democracy. Democratic Theory 4 (1): 59-78.

El-Wakil, Alice, and Francis Cheneval. 2018. Designing popular vote processes to enhance democratic systems. Swiss Political Science Review 24 (3): 348-58.

Fishrin, JAMES S. 2009. When the People Speak: Deliberative Democracy and Public Consultation. Oxford: Oxford University Press. 
Fournier, Patrick, Henk van der Kolk, R. Kenneth Carty, André Blais, and Jonathan Rose. 2011. When Citizens Decide: Lessons from Citizens Assemblies on Electoral Reform. Oxford: Oxford University Press.

Gastil, John, Katherine R. KnOBloch and, Robert Richards. 2015. Building a More Informed Electorate: Analysis of the Citizens' Initiative Review, 2010-2014. State College, PA: Pennsylvania State University.

Gastil, John, Genevieve Fuji Johnson, Soo-Hye Han, and John Rountree. 2017. Assessment of the 2016 Oregon Citizens' Initiative Review on Measure 97. State College, PA: Pennsylvania State University.

GASTIL, JOHN, and ROBERT RICHARDS. 2013. Making direct democracy deliberative through random assemblies. Politics \& Society 41 (2): 253-81.

Gerber, Elisabeth R. 1999. The Populist Paradox: Interest Group Influence and the Promise of Direct Legislation. Princeton, NJ: Princeton University Press.

Hobolt, SARA B. 2010. Campaign financing in Danish referendums. In Financing Referendum Campaigns, edited by Karin Gilland Lutz and Simon Hug. Basingstoke: Palgrave Macmillan, pp. 62-80.

Independent Commission on Referendums. 2018. Report of the Independent Commission on Referendums. London: Constitution Unit.

JoHnSON, PAUL. 2016. What does objectivity mean when reporting on contentious policy issues? The Times, 19 August.

Kahn, Beverly K., Diane M. Strong, and Richard Y. WAng. 2002. Information quality benchmarks: product and service performance. Communications of the ACM 45 (4): 184-92.

KoEHLER, DeREK J. 2016. Can journalistic 'false balance' distort public perception of consensus in expert opinion? Journal of Experimental Psychology: Applied 22 (1): 24-38.

LANDEMORE, HÉLÈnE. 2018. Referendums are never merely referendums: on the need to make popular vote processes more deliberative. Swiss Political Science Review 24 (3): 320-7.

LAU, Richard R., and DAVID P. REDLAwsK (2001). Advantages and Disadvantages of Cognitive Heuristics in Political Decision Making. American Journal of Political Science 45 (4): $951-71$. 
LEDUC, LAWRENCE. 2011. Electoral reform and direct democracy in Canada: when citizens become involved. West European Politics 34 (3): 551-67.

LEDUC, LAWRENCE. 2015. Referendums and deliberative democracy. Electoral Studies 38: $139-48$.

LeDuc, Lawrence, Heather Bastedo, and Catherine Baquero. 2008. The quiet referendum: why electoral reform failed in Ontario. Paper presented at the Annual Meeting of the Canadian Political Science Association, Vancouver, 4-6 June.

LEemann, LuCAS, and FABIO WASSERfallen. 2016. The democratic effect of direct democracy. American Political Science Review 110 (4): 750-62.

Lewis, DANiel C., and MATTHEw L. JACOBSMEIER. 2017. Evaluating policy representation with dynamic MRP estimates: direct democracy and same-sex relationship policies in the United States. State Politics and Policy Quarterly 17 (4): 441-64.

LUPIA, ARTHUR. 1994. Shortcuts versus encyclopedias: information and voting behavior in California insurance reform elections. American Political Science Review 88 (1): 63-76.

LUPIA, ARTHUR. 2016. Uninformed: Why People Know so Little about Politics and What We Can Do about It. New York: Oxford University Press.

Luskin, Robert C., James S. Fishkin, and Roger Jowell (2002). Considered Opinions: Deliberative Polling in Britain. British Journal of Political Science 32 (3): 455-87.

McRobie, Alan. 1993. Educating the public. In Taking It to the People? The New Zealand Electoral Referendum Debate, edited by Alan McRobie. Christchurch: Hazard Press, pp. 4151.

MAYnoR, John W. (2003). Republicanism in the Modern World. Cambridge: Polity Press.

Miller, Holmes. 1996. The multiple dimensions of information quality. Information Systems Management 13 (2): 79-82.

NyHAN, BRENDAN, and JASON REIFLER. 2010. When corrections fail: The persistence of political misperceptions. Political Behavior 32 (2): 303-30.

OfCOM 2017. The Ofcom Broadcasting Code (with the Cross-promotion Code and the On Demand Programme Service Rules), 3 April. Available at https://www.ofcom.org.uk/tvradio-and-on-demand/broadcast-codes/broadcast-code, accessed 13 October 2018. 
OFFE, Claus. 2017. Referendum vs. institutionalized deliberation: what democratic theorists can learn from the 2016 Brexit decision. Daedalus 146 (3): 14-27.

O'MAHOny, JANe. 1998. The Irish referendum experience. Representation 35 (4): 225-36.

O’MAhONy, Jane. 2009. Ireland's EU referendum experience. Irish Political Studies 24 (4): 429-46.

OWens, John R., and LARry L. WAdE. 1986. Campaign spending on California ballot propositions, 1924-1984: trends and voting effects. Western Political Quarterly 39 (4): 67589.

PARKInSON, JOHN. 2009. Beyond 'technique': the role of referendums in the deliberative system. Paper presented to the 'Referendums and Deliberative Democracy' workshop, University of Edinburgh, 8 May.

Parkinson, John, and Jane Mansbridge (eds). 2012. Deliberative Systems: Deliberative Democracy at the Large Scale. Cambridge: Cambridge University Press.

Pateman, Carole (1970). Participation and Democracy Theory. Cambridge: Cambridge University Press.

PetTit, PhiliP (1997). Republicanism: A Theory of Freedom and Government. Oxford: Oxford University Press.

PILON, DENNIS. 2009. Investigating media as a deliberative space: newspaper opinions about voting systems in the 2007 Ontario provincial referendum. Canadian Political Science Review 3 (3): 1-23.

RATNER, R. S. 2008. Communicative rationality in the citizens' assembly and referendum processes. In Designing Deliberative Democracy: The British Columbia Citizens' Assembly, edited by Mark E. Warren and Hilary Pearse. Cambridge: Cambridge University Press, pp. $145-65$.

Renwick, Alan. 2017. Referendums. In The Sage Handbook of Electoral Behaviour, edited by Kai Arzheimer, Jocelyn Evans, and Michael Lewis-Beck. London: Sage, pp. 433-58.

Renwick, Alan, and Michael Lamb. 2013. The quality of referendum debate: the UK's electoral system referendum in the print media. Electoral Studies 32 (2): 294-304. 
Renwick, Alan, and Michela Palese. 2019. Doing Democracy Better: How Can Information and Discourse in Election and Referendum Campaigns in the UK Be Improved? London: Constitution Unit.

RENWICK, Alan, and Jess SARgEANT. Forthcoming. The Rules of referendums. In Palgrave Handbook on European Referendums, edited by Julie Smith. Basingstoke: Palgrave.

Renwick, Alan, and JaCK Vowles. 2019. Tales of two referendums: comparing debate quality between the UK and New Zealand voting system referendums of 2011. Unpublished.

Rogers, TodD, and JoEl MiddLeton. 2014. Are ballot initiative outcomes influenced by the campaigns of independent groups? A precinct-randomized field experiment showing that they are. Political Behavior 37 (3): 567-93.

Rosenbluth, Frances McCall, and Ian Shapiro. 2018. Responsible Parties: Saving Democracy from Itself. New Haven: Yale University Press.

SETÄLÄ, MAIJA. 2006. On the problems of responsibility and accountability in referendums. European Journal of Political Research 45: 699-721.

Steiner, JÜrG, ANDrÉ BÄChtiger, MARkUs SpÖRndli, and MARCo R. STEENBERGEN. 2004. Deliberative Politics in Action: Analysing Parliamentary Discourse. Cambridge: Cambridge University Press.

Stubley, Peter. 2018. BBC was not impartial during Brexit referendum, ITV's Robert Peston says. Independent, 6 October.

SUITER, JANE. 2018a. Lessons from Ireland's recent referendums: how deliberation helps inform voters. LSE British Politics and Policy blog, 10 September.

SuITER, JANE. 2018b. Deliberation in action - Ireland's abortion referendum. Political Insight 9 (3): 30-2.

SunsteIn, Cass R. 2002. The law of group polarization. Journal of Political Philosophy 10 (2): 175-95.

Thorson, Emily. 2016. Belief echoes: the persistent effects of corrected misinformation. Political Communication 33 (3): 460-80. 
VOWLES, JACK. 2013. Campaign claims, partisan cues, and media effects in the 2011 British electoral system referendum. Electoral Studies 32 (2): 253-64.

Warren, Mark E., and Hilary Pearse. 2008. Designing Deliberative Democracy: The British Columbia Citizens’ Assembly. Cambridge: Cambridge University Press.

Wood, ThOmas, and Ethan PorTer. 2019. The elusive backfire effect: mass attitudes' steadfast factual adherence. Political Behavior 41 (1): 135-63. 